Supporting Information for

\title{
Terazulene isomers: polarity change of OFETs through molecular orbital distribution contrast
}

Yuji Yamaguchi ${ }^{\dagger}$, Maki Takubo $^{\dagger}$, Keisuke Ogawa ${ }^{\dagger}$, Ken-ichi Nakayama ${ }^{\dagger}$,Tomoyuki Koganezawa ${ }^{\S}$ Hiroshi Katagiri* ${ }^{\dagger}$

${ }^{\dagger}$ Graduate School of Science and Engineering, Yamagata University, 4-3-16 Jonan, Yonezawa, Yamagata 992-8510, Japan

§Japan Synchrotron Radiation Research Institute (JASRI), SPring-8, 1-1-1 Kouto, Sayo, Hyogo 679-5198, Japan

\section{Contents}

1. Synthesis

2. NMR Spectra

3. HR-MS Spectra

4. TGA Analysis

5. Single-crystal X-ray Crystallography

6. Device Fabrications and Evaluations

7. Thin film X-ray diffraction measurement

8. Theoretical Calculations

9. References 


\section{Experimental Section}

General: All chemicals and solvents were reagent-grade quality, obtained commercially, and used without further purification except as noted. All reactions were performed in standard, dry glassware under an inert atmosphere of nitrogen. Column chromatography was performed using Kanto silica gel $60 \mathrm{~N}$, spherical neutral, 40-100 $\mu \mathrm{m}$. Thin-layer chromatography (TLC) was performed using pre-coated aluminum sheets covered with $0.20 \mathrm{~mm}$ silica gel with a UV-fluorescent indicator $(\lambda=$ $254 \mathrm{~nm}$ ). Melting points were determined with a SANSYO SMP-300. Nuclear magnetic resonance spectra were obtained using a JEOL JNM-ECX operated at $500 \mathrm{MHz}$ for ${ }^{1} \mathrm{H}$ or $125 \mathrm{MHz}$ for ${ }^{13} \mathrm{C}$. The samples for NMR were dissolved in deuterated chloroform containing tetramethylsilane (TMS) as an internal reference; chemical shifts $(\delta)$ are reported in parts per million. Elemental analyses were performed on a Perkin Elmer 2400 series II CHNS/O elemental analyzer.

Physicochemical Studies: UV-vis spectra were measured on a JASCO V-650 spectrophotometer. Photoemission yield spectroscopy (PYS) was performed on a RIKEN KEIKI AC-3. Thin film X-ray diffraction (XRD) patterns were recorded on a Rigaku Smartlab system. Thermogravimetric analysis (TGA) was performed on a SII TG/DTA 6200. Atomic force microscopy (AFM) images were recorded on a Bruker Dimension Icon.

\section{Synthesis}

Dimethyl 2'-chloro-6,6'-biazulene-1',1'-dicarboxylate (5):
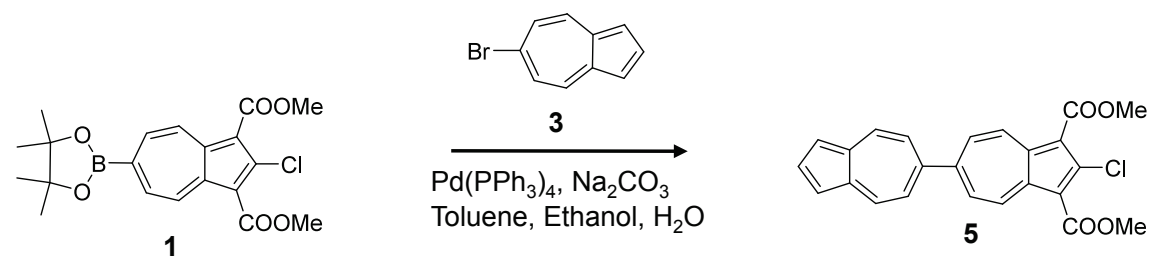

A mixture of $\mathrm{Pd}\left(\mathrm{PPh}_{3}\right)_{4}(170 \mathrm{mg}, 0.147 \mathrm{mmol})$, 6-bromoazulene $(3,1.00 \mathrm{~g}, 4.83 \mathrm{mmol})$, dimethyl 2-chloro-6-(4,4,5,5-tetramethyl-1,3,2-dioxaborolan-2-yl)azulene-1,3-dicarboxylate ${ }^{1)}$ (1, 2.34 g, 5.77 $\mathrm{mmol})$, and $2 \mathrm{M} \mathrm{NaHCO}_{3}$ aq. $(15.5 \mathrm{ml})$ in a mixture of toluene $(31 \mathrm{ml})$ and $\mathrm{EtOH}(16 \mathrm{ml})$ was refluxed for $18 \mathrm{~h}$ under a nitrogen atmosphere. The mixture was poured into water $(200 \mathrm{ml})$ and extracted with dichloromethane. The organic phase was dried over $\mathrm{Na}_{2} \mathrm{SO}_{4}$ and concentrated under reduced pressure. The residue was purified by column chromatography on silica gel with dichloromethane/ethyl acetate (9:1) as the eluent to give 5 (1.61 g, 82\%). Dark-green crystals; mp $221.9{ }^{\circ} \mathrm{C} ;{ }^{1} \mathrm{H}$ NMR $\left(500 \mathrm{MHz}, \mathrm{CDCl}_{3}\right) \delta(\mathrm{ppm}) 9.59(\mathrm{~d}, J=10.77 \mathrm{~Hz}, 2 \mathrm{H}), 8.46(\mathrm{~d}, J=10.20 \mathrm{~Hz}$, $2 \mathrm{H}), 8.03-7.98(\mathrm{~m}, 3 \mathrm{H}), 7.51(\mathrm{~d}, J=3.97 \mathrm{~Hz}, 2 \mathrm{H}), 7.34(\mathrm{~d}, J=10.20 \mathrm{~Hz}, 2 \mathrm{H}), 4.05(\mathrm{~s}, 6 \mathrm{H}) ;{ }^{13} \mathrm{C}$ NMR (125 MHz, $\left.\mathrm{CDCl}_{3}\right) \delta(\mathrm{ppm}) 164.81,157.96,152.02,143.85,140.88,139.44,138.79,137.34$, 
135.74, 132.39, 123.95, 119.63, 115.69, 51.81; Anal. Calcd for $\mathrm{C}_{24} \mathrm{H}_{17} \mathrm{Cl}$ : C, 71.20; H, 4.23 Found: $\mathrm{C}$, $71.21 ; \mathrm{H}, 4.27$.

\section{2'-Chloro-6,6'-biazulene (7):}

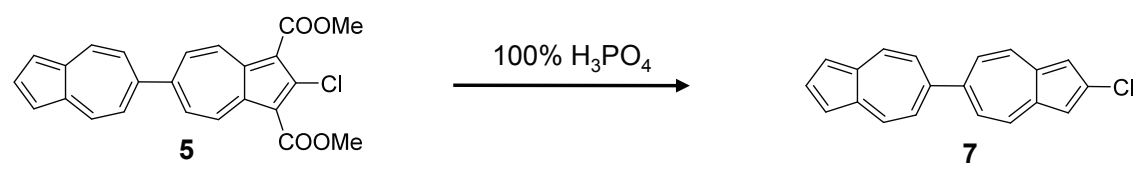

A mixture of dimethyl 2'-chloro-6,6'-biazulene-1', $1^{\prime}$-dicarboxylate $(5,1.14 \mathrm{~g}, 2.81 \mathrm{mmol})$ and $100 \%$ phosphoric acid was heated at $90{ }^{\circ} \mathrm{C}$ for $30 \mathrm{~min}$. After the reaction mixture was cooled, it was poured into ice-water $(400 \mathrm{ml})$ and the resultant precipitate was collected by filtration. The residue was washed sequentially with methanol, hexane, and chloroform to give 7 (510 $\mathrm{mg}, 63 \%$ ). Dark-green crystals; mp $>300{ }^{\circ} \mathrm{C} ;{ }^{1} \mathrm{H}$ NMR $\left(500 \mathrm{MHz}\right.$, DMSO- $\left.d_{6}\right) \delta(\mathrm{ppm}) 8.54(\mathrm{~d}, J=10.20 \mathrm{~Hz}$, 2H), 8.49 (d, $J=10.20 \mathrm{~Hz}, 2 \mathrm{H}), 7.98(\mathrm{dd}, J=6.80,6.80 \mathrm{~Hz}, 1 \mathrm{H}), 7.64(\mathrm{~d}, J=10.20 \mathrm{~Hz}, 2 \mathrm{H}), 7.51-$ 7.49 (m, 4H), 7.46 (s, 2H); Anal. Calcd for $\mathrm{C}_{20} \mathrm{H}_{13} \mathrm{Cl}$ : C, 83.19; H, 4.54 Found: C, 82.89; H, 4.41.

\section{$2,2^{\prime}: 6^{\prime}, 2^{\prime \prime}-$ Terazulene (TAz2):}

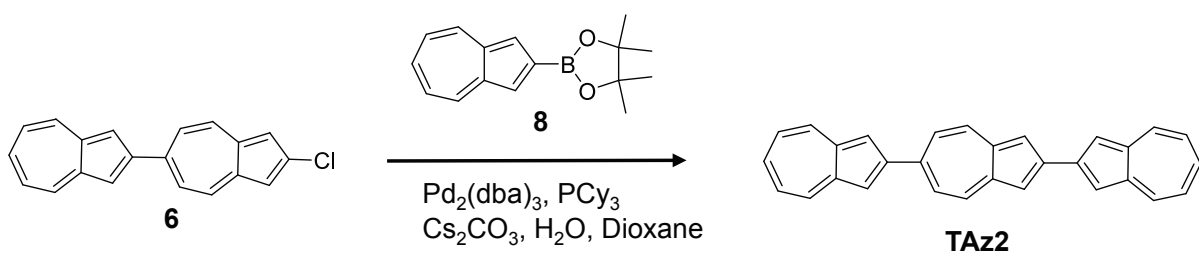

A mixture of $\mathrm{Pd}_{2}(\mathrm{dba})_{3}(86.0 \mathrm{mg}, 0.09 \mathrm{mmol}), \mathrm{PCy}_{3}(52 \mathrm{mg}, 0.19 \mathrm{mmol}), 2^{\prime}$-chloro-2,6'-biazulene (6, $660 \mathrm{mg}, 2.29 \mathrm{mmol}), 6$-(4,4,5,5-tetramethyl-1,3,2-dioxaborolan-2-yl)azulene (8, $630 \mathrm{mg}, 2.48$ $\mathrm{mmol})$, and $1.3 \mathrm{M} \mathrm{Cs}_{2} \mathrm{CO}_{3}$ aq. $(12 \mathrm{ml})$ in dioxane $(150 \mathrm{ml})$ was refluxed for $21 \mathrm{~h}$ under a nitrogen atmosphere. The mixture was poured into water $(500 \mathrm{ml})$, and the resultant precipitate was collected by filtration. The residue was washed with methanol, hexane, and then dichloromethane, and the precipitate was purified by gradient sublimation to give TAz2 (140 mg, 13\%). Dark-green crystals; $\mathrm{mp}>300{ }^{\circ} \mathrm{C}$; Anal. Calcd for $\mathrm{C}_{30} \mathrm{H}_{20}$ : C, 94.70; H, 5.30. Found: C, 94.73; H, 5.25. 


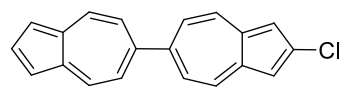

7
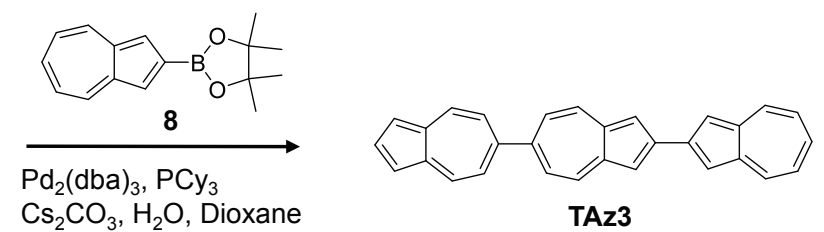

A mixture of $\mathrm{Pd}_{2}(\mathrm{dba})_{3}(49.0 \mathrm{mg}, 0.053 \mathrm{mmol}), \mathrm{PCy}_{3}$ (30 mg, $0.11 \mathrm{mmol}$ ), 2'-chloro-6,6'-biazulene (7, $382 \mathrm{mg}, 1.32 \mathrm{mmol})$, 6-(4,4,5,5-tetramethyl-1,3,2-dioxaborolan-2-yl)azulene (8, $371 \mathrm{mg}, 1.46$ $\mathrm{mmol}), 1.3 \mathrm{M} \mathrm{Cs}_{2} \mathrm{CO}_{3}$ aq. $(8 \mathrm{ml})$ in dioxane $(95 \mathrm{ml})$ was refluxed for $16 \mathrm{~h}$ under a nitrogen atmosphere. The mixture was poured into water $(500 \mathrm{ml})$, and the resultant precipitate was collected by filtration. The residue was washed sequentially with methanol, hexane, and dichloromethane, and the precipitate was purified by gradient sublimation to give TAz3 (34.5 mg, 7\%). Dark-green crystals; $\mathrm{mp}>300{ }^{\circ} \mathrm{C}$; Anal. Calcd for $\mathrm{C}_{30} \mathrm{H}_{20}$ : C, 94.70; H, 5.30. Found: C, 94.71; H, 5.37.

\section{6,2':6',6"-Terazulene (TAz4):}
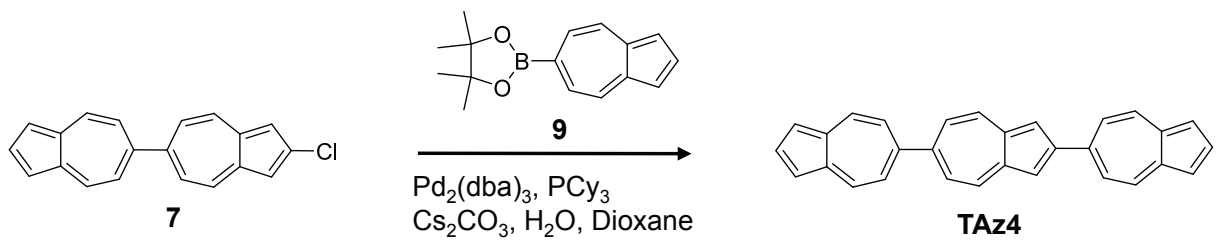

A mixture of $\quad \mathrm{Pd}_{2}(\mathrm{dba})_{3} \quad\left(\begin{array}{lllllll}25.0 & \mathrm{mg}, & 0.027 & \mathrm{mmol}\end{array}\right), \mathrm{PCy}_{3} \quad\left(\begin{array}{llll}15 & \mathrm{mg}, & 0.053 & \mathrm{mmol}\end{array}\right)$, 2'-chloro-6,6'-biazulene

(7,

185

$\mathrm{mg}$,

0.641

$\mathrm{mmol})$,

6-(4,4,5,5-tetramethyl-1,3,2-dioxaborolan-2-yl)azulene (9, $180 \mathrm{mg}, 0.708 \mathrm{mmol}), 1.3 \mathrm{M} \mathrm{Cs}_{2} \mathrm{CO}_{3}$ aq. $(3.4 \mathrm{ml})$ in dioxane $(46 \mathrm{ml})$ was refluxed for $16 \mathrm{~h}$ under nitrogen atmosphere. The mixture was poured into water $(500 \mathrm{ml})$, and the resultant precipitate was collected by filtration. The residue was washed sequentially with methanol, hexane, and dichloromethane, and the precipitate was purified by gradient sublimation to give TAz4 (47.6 mg, 20\%). Dark-green crystals; mp $>300{ }^{\circ} \mathrm{C}$; Anal. Calcd for $\mathrm{C}_{30} \mathrm{H}_{20}$ : C, 94.70; H, 5.30. Found: C, 94.70; H, 5.15. 


\section{NMR Spectra}

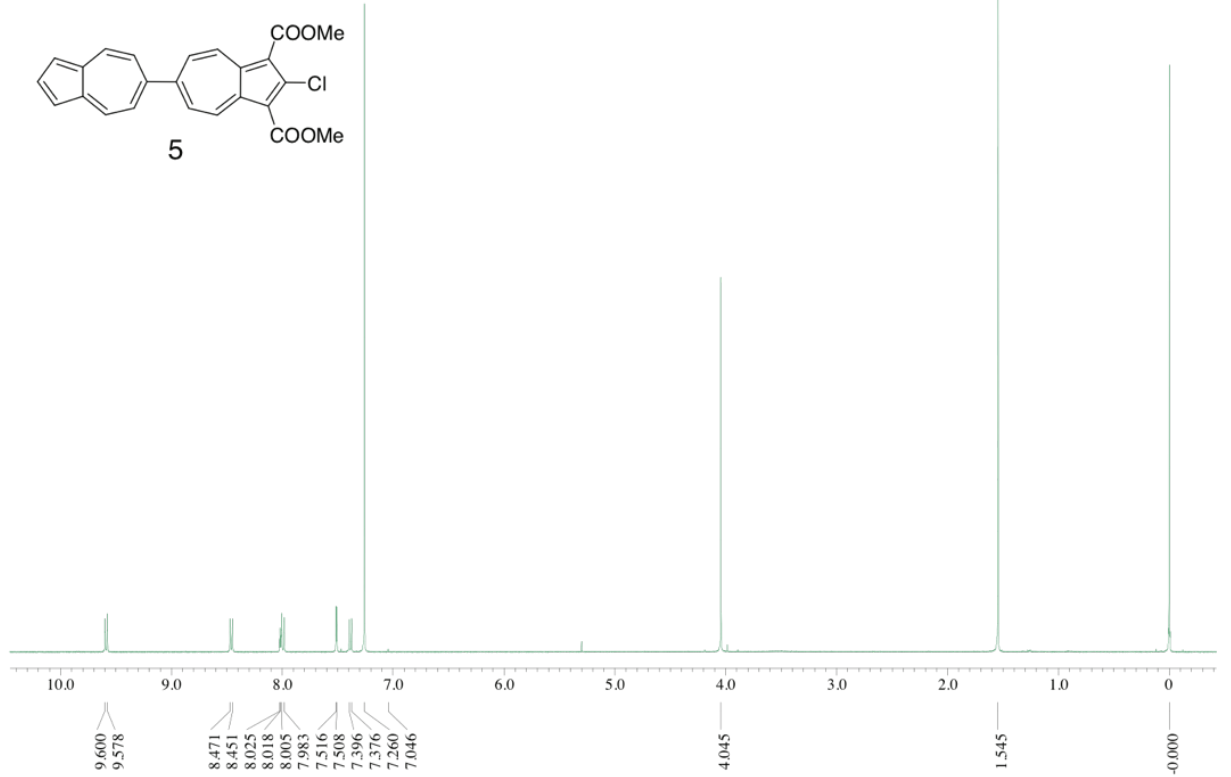

Figure S1. ${ }^{1} \mathrm{H}$ NMR spectrum of $5\left(500 \mathrm{MHz}, \mathrm{CDCl}_{3}, 25^{\circ} \mathrm{C}\right)$.

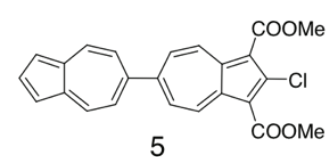

5

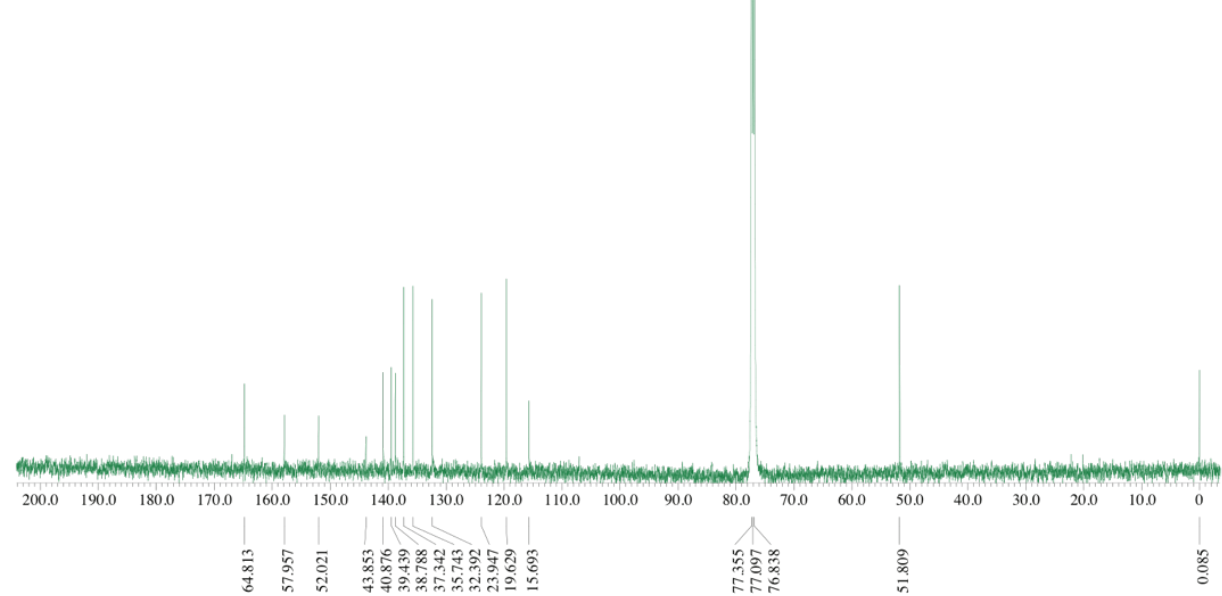

Figure S2. ${ }^{13} \mathrm{C}$ NMR spectrum of $5\left(125 \mathrm{MHz}, \mathrm{CDCl}_{3}, 25{ }^{\circ} \mathrm{C}\right)$. 


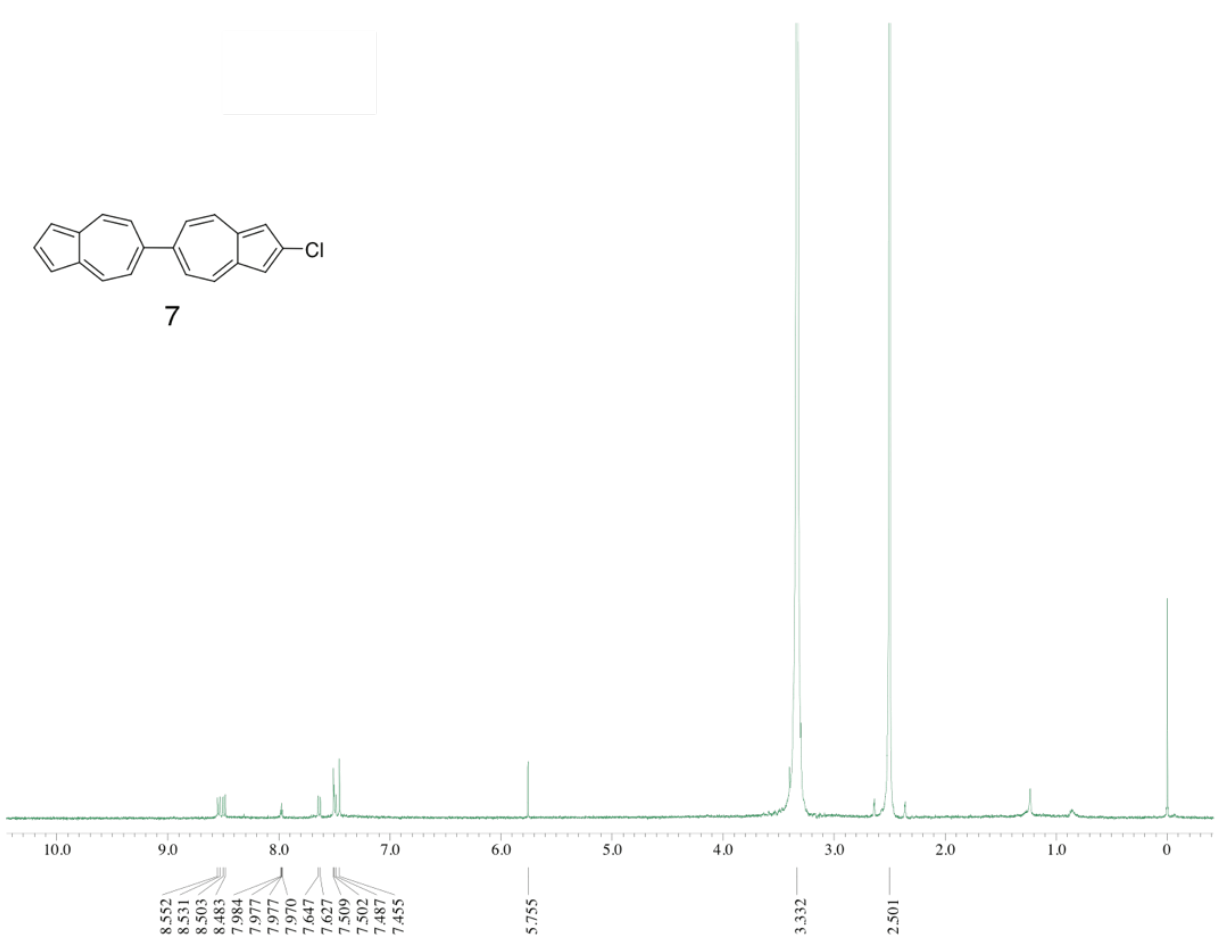

Figure S3. ${ }^{1} \mathrm{H}$ NMR spectrum of $7\left(500 \mathrm{MHz}, \mathrm{DMSO}-d_{6}, 25^{\circ} \mathrm{C}\right)$.
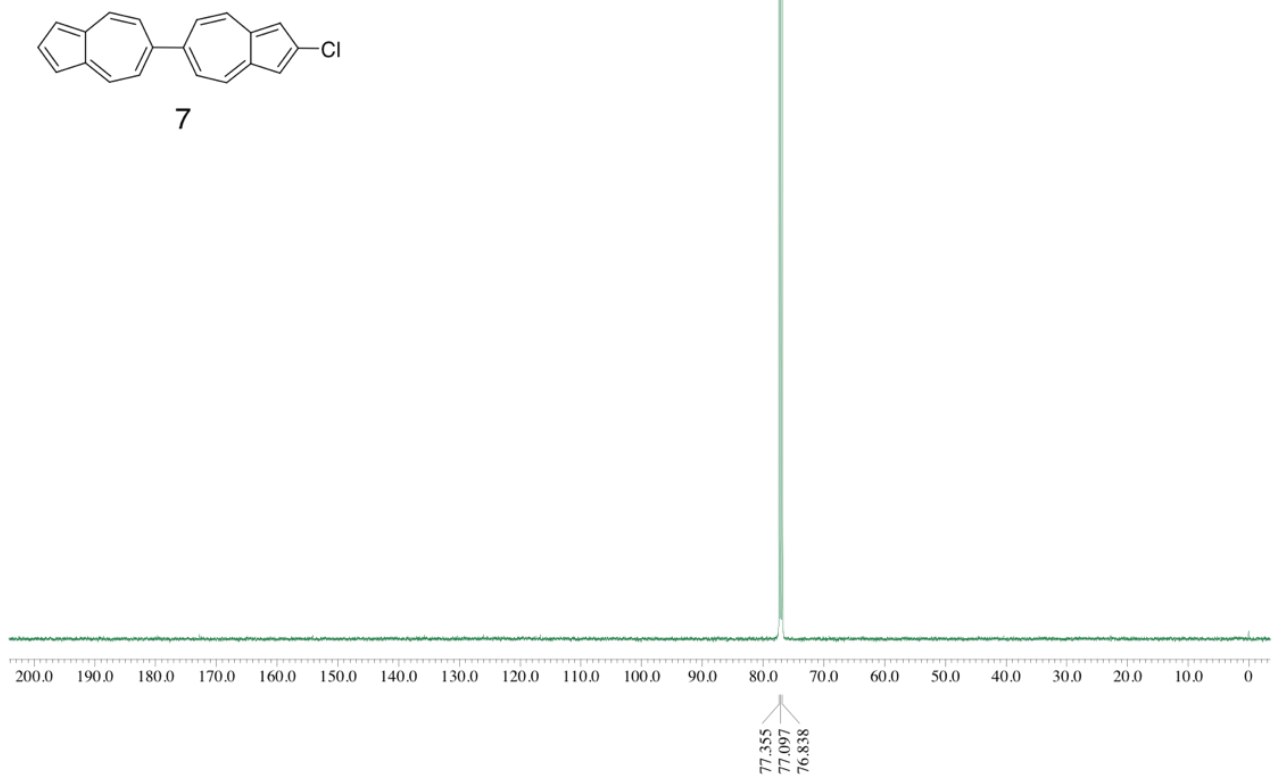

Figure S4. ${ }^{13} \mathrm{C}$ NMR spectrum of $7\left(125 \mathrm{MHz}, \mathrm{CDCl}_{3}, 25{ }^{\circ} \mathrm{C}\right)$. 


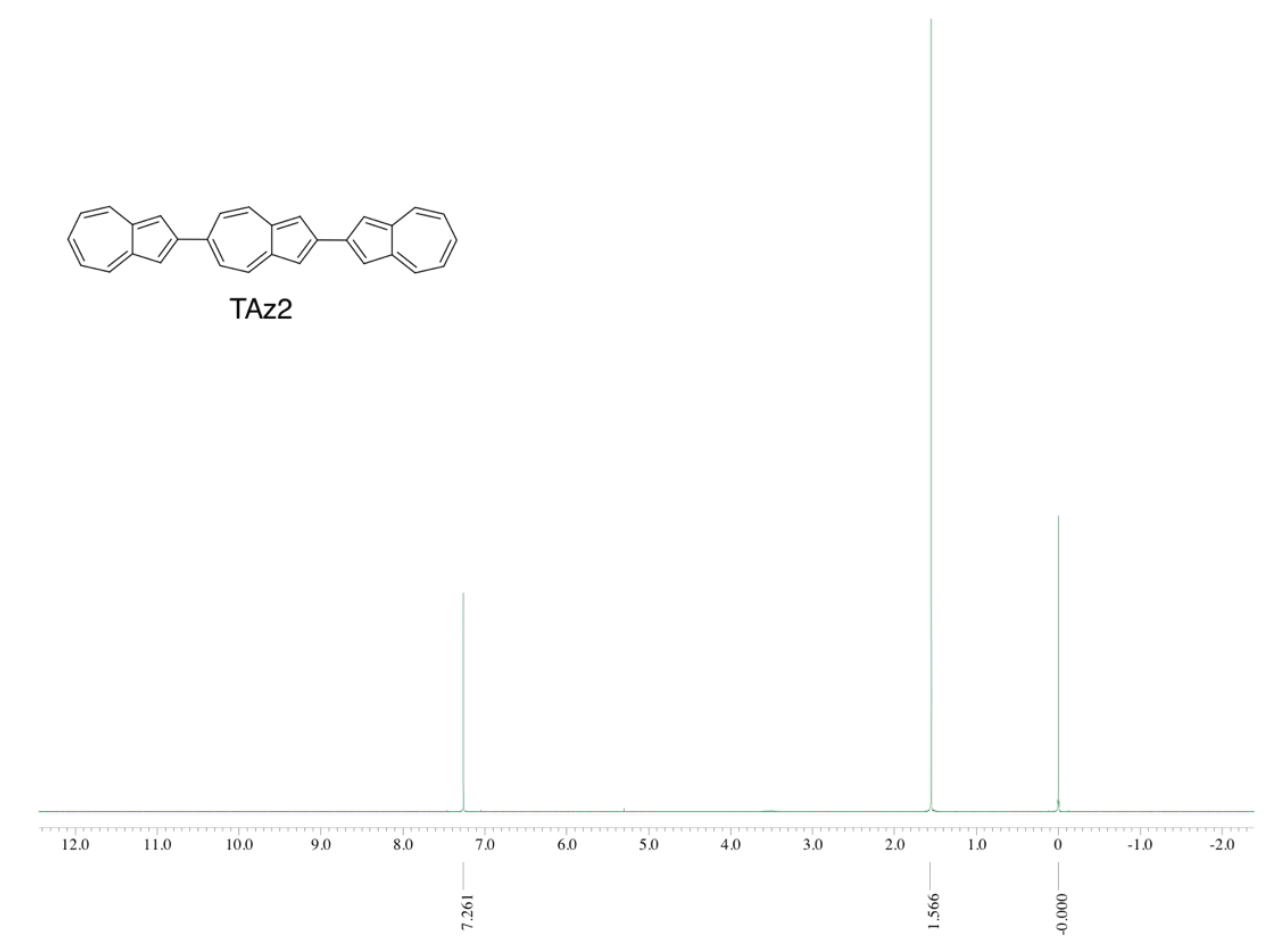

Figure S5. ${ }^{1} \mathrm{H}$ NMR spectrum of $\mathbf{T A z 2}\left(500 \mathrm{MHz}, \mathrm{CDCl}_{3}, 25^{\circ} \mathrm{C}\right)$.

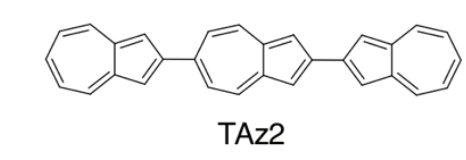

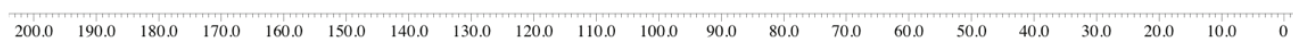

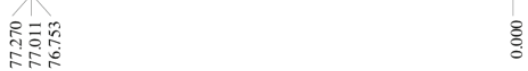

Figure S6. ${ }^{13} \mathrm{C}$ NMR spectrum of $\mathbf{T A z 2}\left(125 \mathrm{MHz}, \mathrm{CDCl}_{3}, 25^{\circ} \mathrm{C}\right)$. 

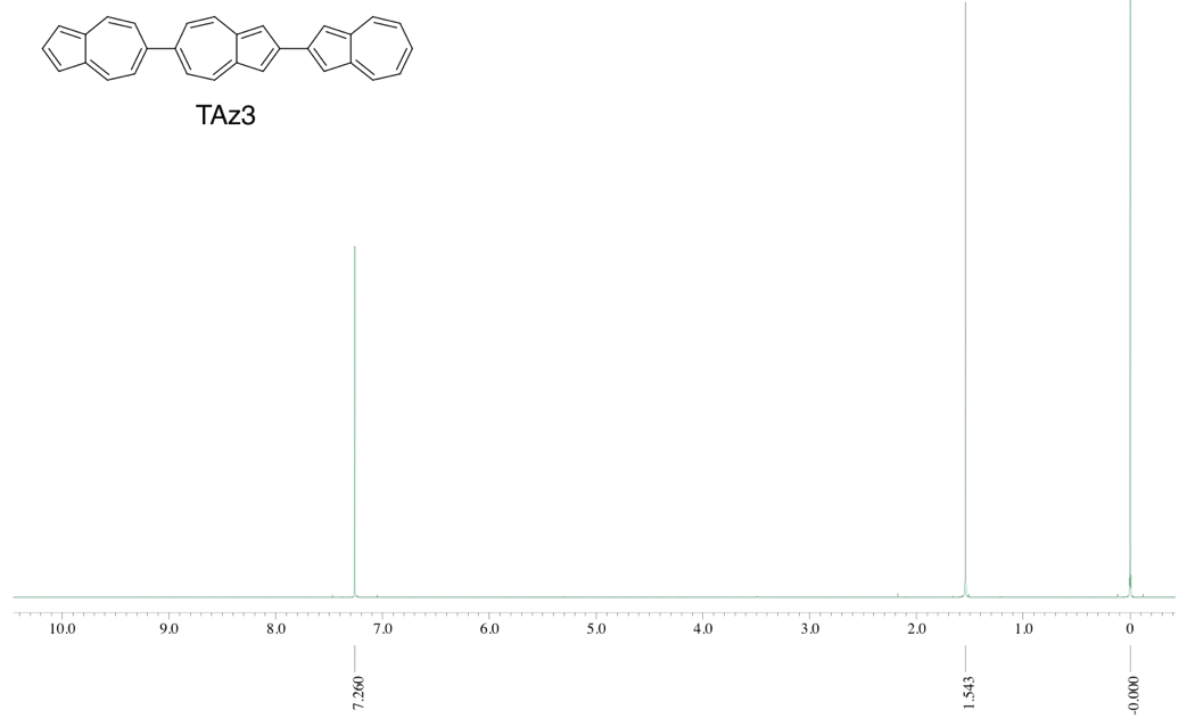

Figure S7. ${ }^{1} \mathrm{H}$ NMR spectrum of $\mathbf{T A z 3}\left(500 \mathrm{MHz}, \mathrm{CDCl}_{3}, 2{ }^{\circ} \mathrm{C}\right)$.
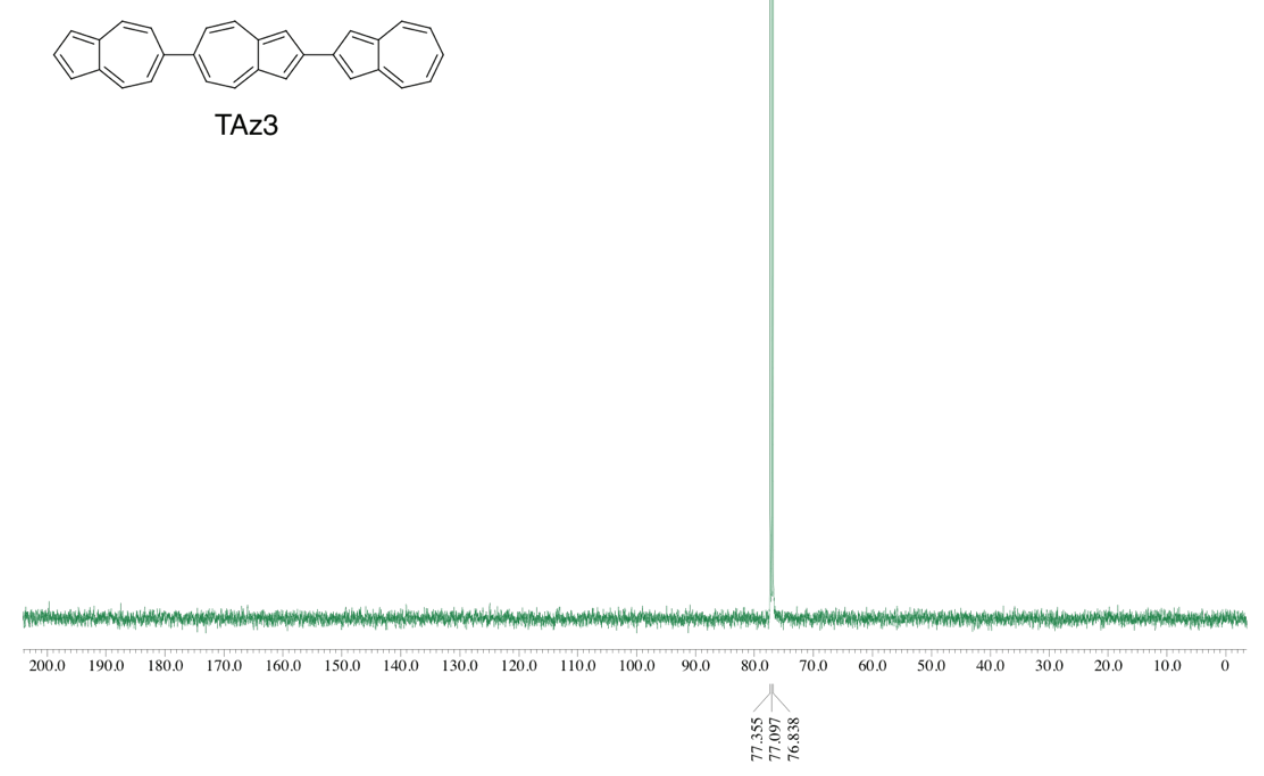

Figure S8. ${ }^{13} \mathrm{C}$ NMR spectrum of $\mathbf{T A z 3}\left(125 \mathrm{MHz}, \mathrm{CDCl}_{3}, 25{ }^{\circ} \mathrm{C}\right)$. 


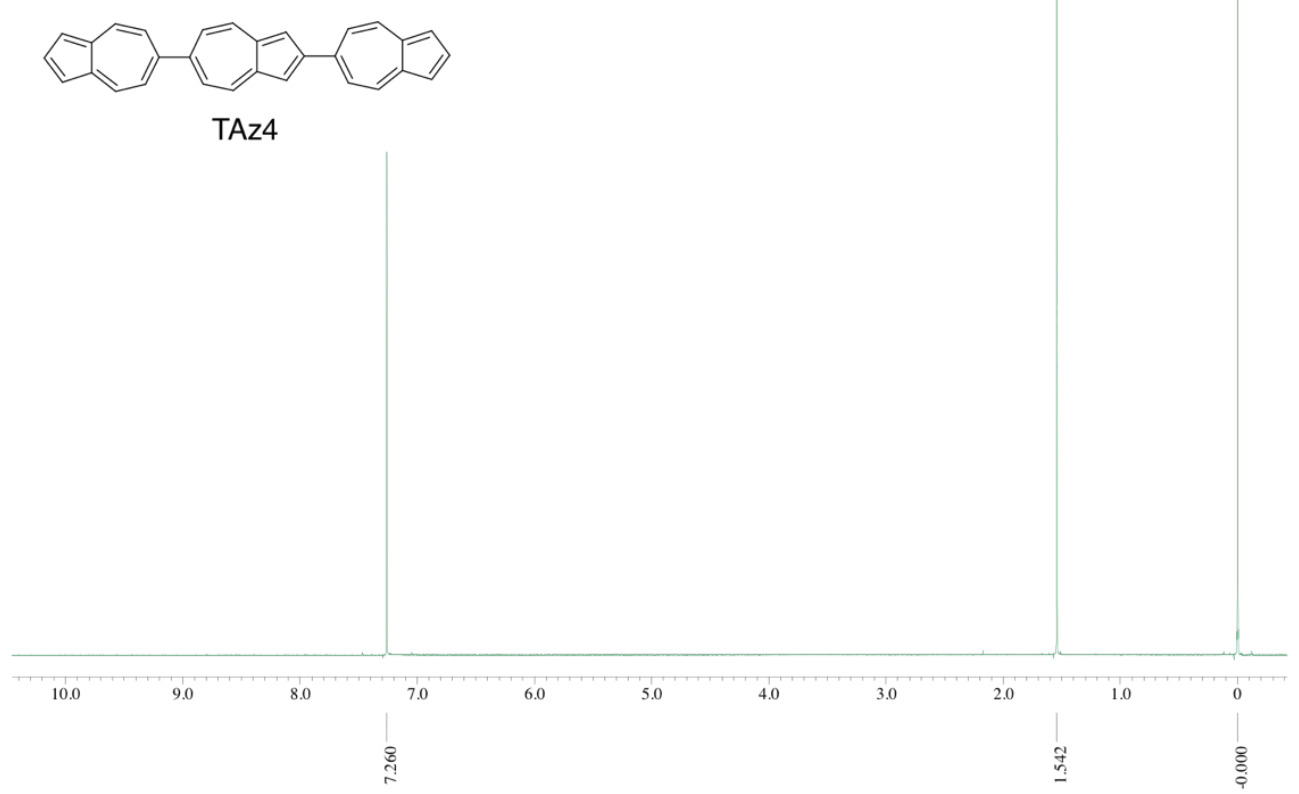

Figure S9. ${ }^{1} \mathrm{H}$ NMR spectrum of TAz4 $\left(500 \mathrm{MHz}, \mathrm{CDCl}_{3}, 25^{\circ} \mathrm{C}\right)$.

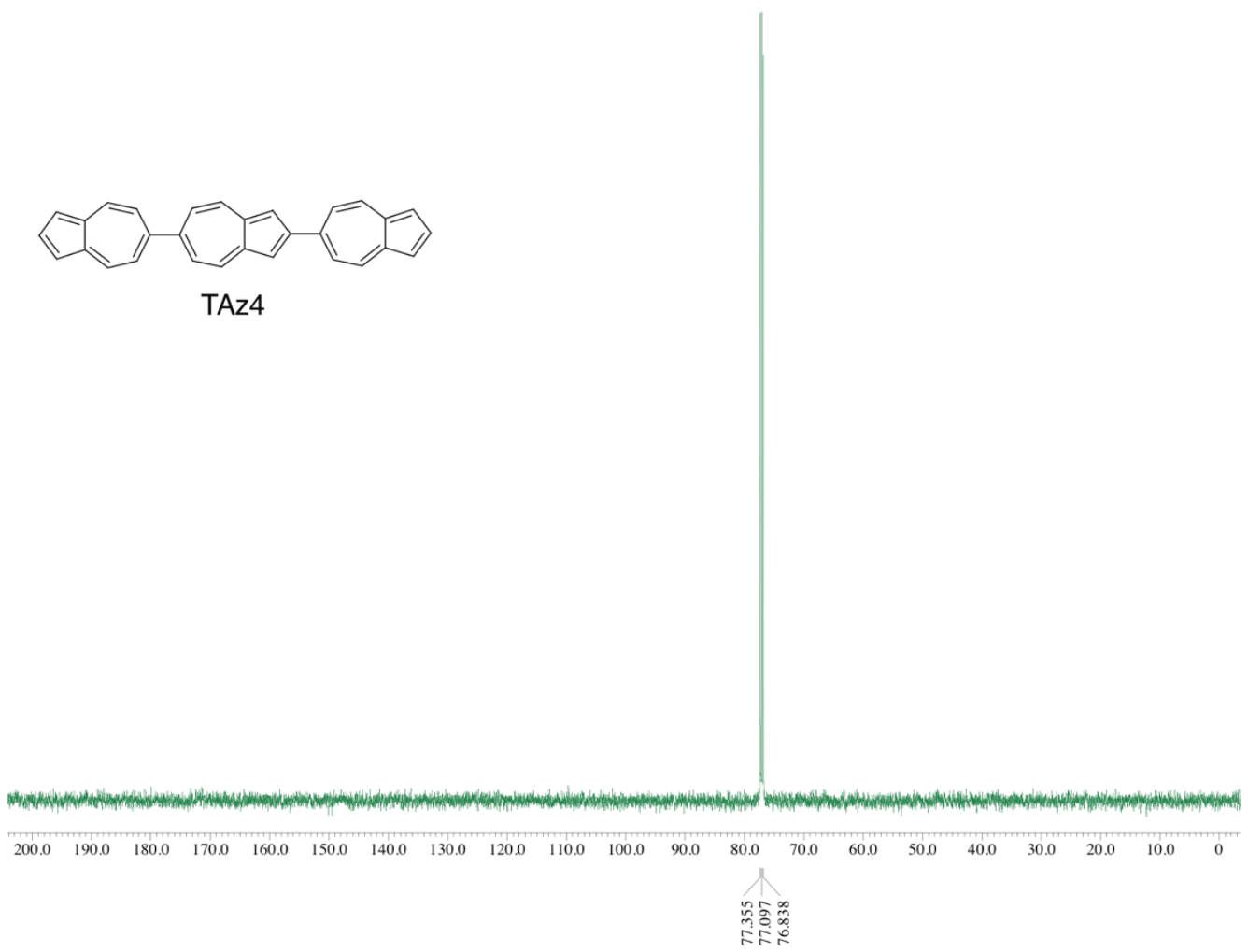

Figure S10. ${ }^{13} \mathrm{C}$ NMR spectrum of TAz4 $\left(125 \mathrm{MHz}, \mathrm{CDCl}_{3}, 25^{\circ} \mathrm{C}\right)$. 


\section{FD-HRMS Spectra}

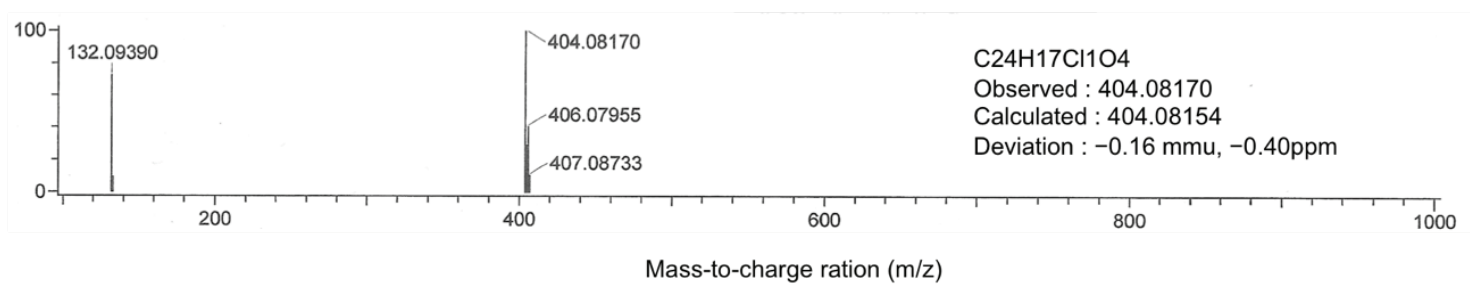

Figure S11. FD-HRMS spectrum of 5 with tetralin (calcd for $\mathrm{C}_{10} \mathrm{H}_{12}\left(\mathrm{M}^{+}\right): \mathrm{m} / z=132.09390$ ) as an internal standard.

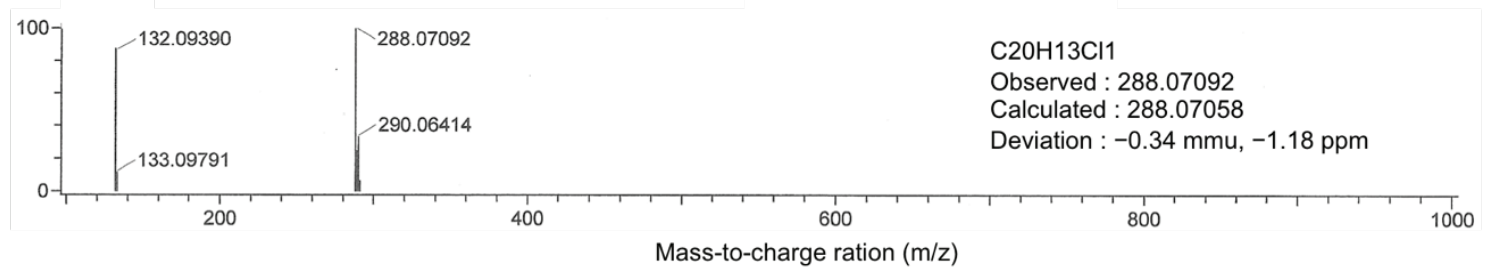

Figure S12. FD-HRMS spectrum of 7 with tetralin (calcd for $\mathrm{C}_{10} \mathrm{H}_{12}\left(\mathrm{M}^{+}\right): \mathrm{m} / z=132.09390$ ) as an internal standard.

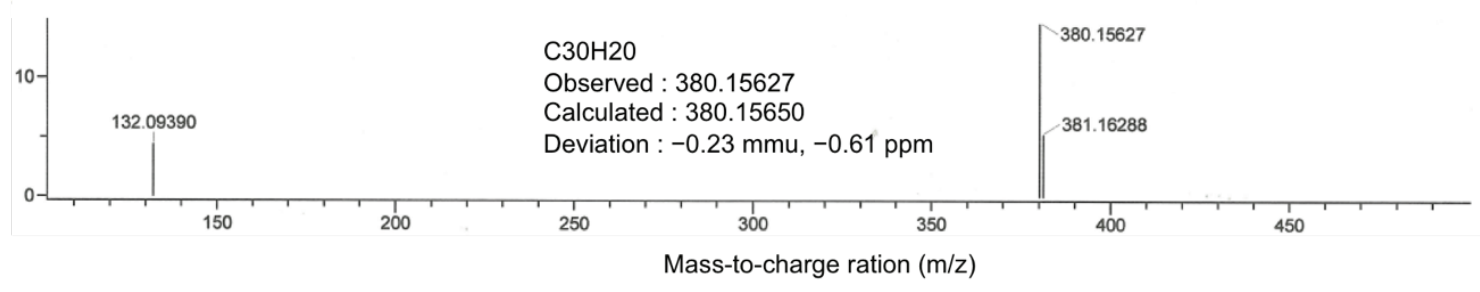

Figure S13. FD-HRMS spectrum of TAz2 with tetralin (calcd for $\left.\mathrm{C}_{10} \mathrm{H}_{12}\left(\mathrm{M}^{+}\right): \mathrm{m} / z=132.09390\right)$ as an internal standard.

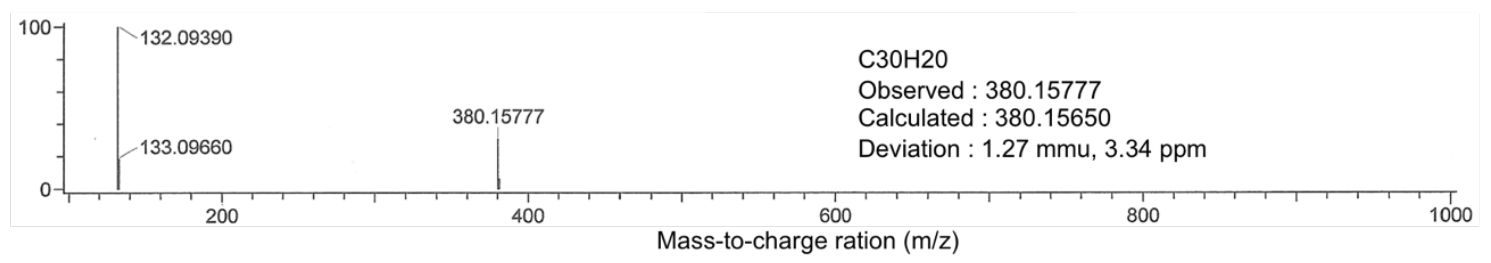

Figure S14. FD-HRMS spectrum of TAz3 with tetralin (calcd for $\mathrm{C}_{10} \mathrm{H}_{12}\left(\mathbf{M}^{+}\right): \mathrm{m} / \mathrm{z}=132.09390$ ) as an internal standard. 


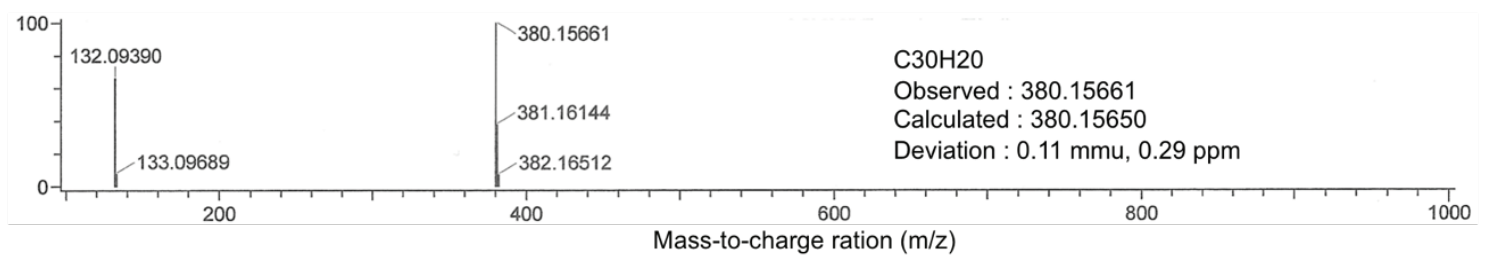

Figure S15. FD-HRMS spectrum of TAz4 with tetralin (calcd for $\mathrm{C}_{10} \mathrm{H}_{12}\left(\mathrm{M}^{+}\right): \mathrm{m} / \mathrm{z}=132.09390$ ) as an internal standard.

\section{TGA analysis}
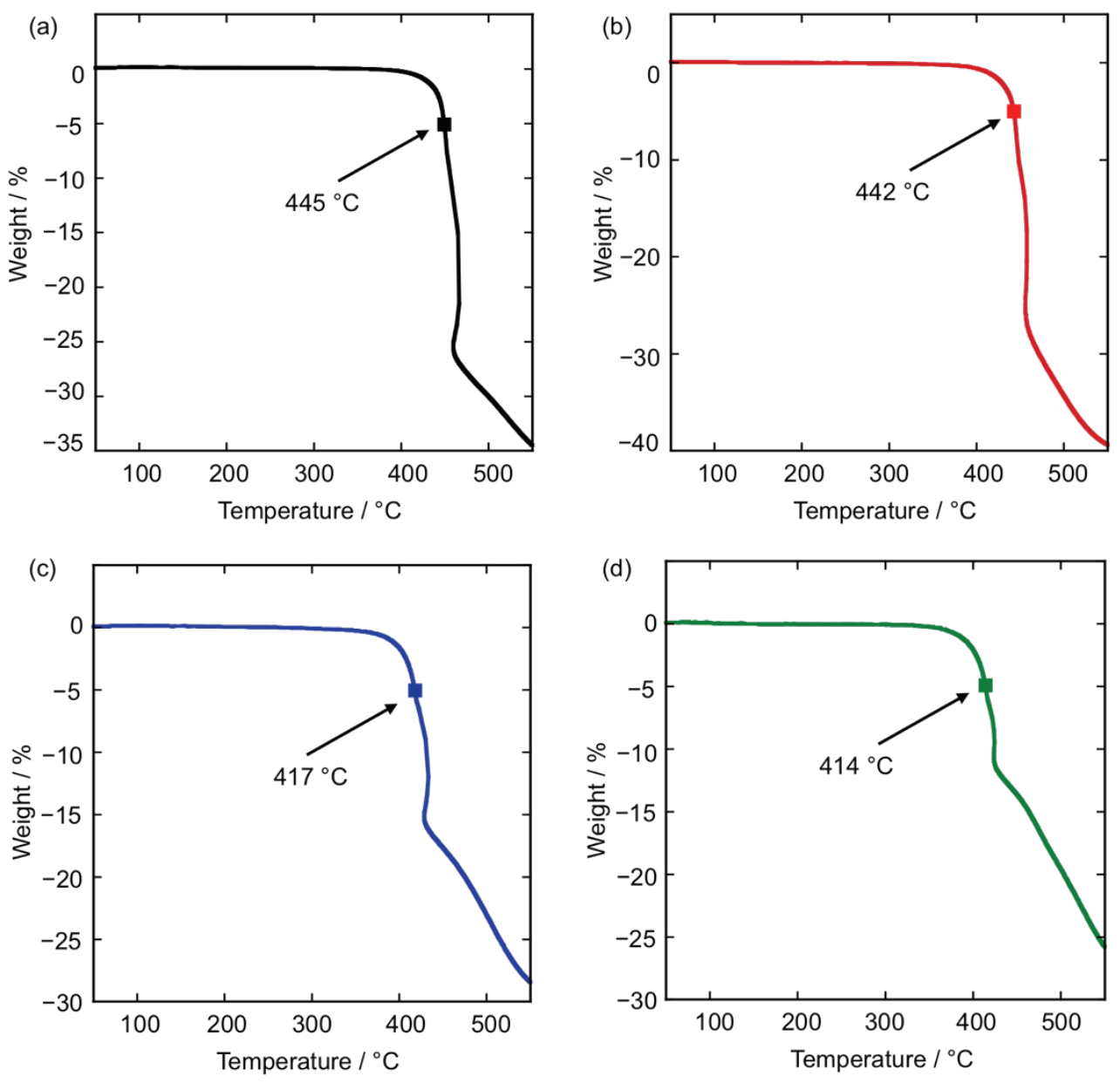

Figure S16. TGA traces for terazulene isomers: (a) TAz1, ${ }^{1)}$ (b) TAz2, (c) TAz3, and (d) TAz4. The heating rate was $10{ }^{\circ} \mathrm{C} / \mathrm{min}$ under an $\mathrm{N}_{2}$ atmosphere. 


\section{Single-crystal X-ray Crystallography.}

X-Ray diffraction data for TAz2-4 were collected at $93 \mathrm{~K}$ on a Rigaku Saturn $724 \mathrm{CCD}$ diffractometer using Mo- $K \alpha$ radiation $(\lambda=0.71075 \AA)$. Single crystals of TAz2-4 $\left[C_{30} \mathrm{H}_{20}, \mathrm{Mw}=\right.$ 380.46] suitable for X-ray analyses were grown by slow gradient sublimation, and dark-green crystals were selected for intensity measurements. All terazulene crystal data and structure refinements are listed in Table S1. Data collection, cell refinements, and data reductions were conducted using the CrysAlisPro software. ${ }^{2)}$ These structures were solved by direct methods using the program SHELXT ${ }^{3)}$ and were refined by full-matrix least-squares methods on $F^{2}$ using SHELXL2014. ${ }^{4)}$ All materials for publication were prepared using the Yadokari-XG 2009 software. ${ }^{5)}$ All non-hydrogen atoms were refined anisotropically. The positions of all hydrogen atoms were calculated geometrically and refined using a riding model.

Table S1. Crystal data and structure refinement for TAz2-4.

\begin{tabular}{|c|c|c|c|}
\hline Compound & TAz2 & TAz3 & TAz4 \\
\hline Empirical formula & $\mathrm{C}_{30} \mathrm{H}_{20}$ & $\mathrm{C}_{30} \mathrm{H}_{20}$ & $\mathrm{C}_{30} \mathrm{H}_{20}$ \\
\hline Formula weight & 380.46 & 380.46 & 380.46 \\
\hline Temperature (K) & 93 & 93 & 93 \\
\hline Wavelength $(\AA)$ & 0.71073 & 0.71073 & 0.71073 \\
\hline Crystal system & Triclinic & Monoclinic & Triclinic \\
\hline Space group & $P-1$ & $P C$ & $P 1$ \\
\hline$a(\AA)$ & $5.917(4)$ & $5.9450(8)$ & $6.0461(3)$ \\
\hline$b(\AA)$ & $7.782(4)$ & $7.2440(11)$ & $7.3963(4)$ \\
\hline$c(\AA)$ & $20.718(12)$ & $40.577(7)$ & $20.9073(11)$ \\
\hline$\alpha\left(^{\circ}\right)$ & $81.545(15)$ & 90 & $81.327(5)$ \\
\hline$\beta\left(^{\circ}\right)$ & $87.448(16)$ & $91.345(14)$ & $89.655(4)$ \\
\hline$\gamma\left({ }^{\circ}\right)$ & $89.023(18)$ & 90 & $88.536(4)$ \\
\hline Volume $\left(\AA^{3}\right)$ & $942.6(9)$ & $1747.0(5)$ & $923.95(8)$ \\
\hline$Z$ & 2 & 4 & 2 \\
\hline Density (calculated) $\left(\mathrm{g} / \mathrm{cm}^{3}\right)$ & 1.340 & 1.447 & 1.368 \\
\hline Absorption coefficient $\left(\mathrm{mm}^{-1}\right)$ & 0.076 & 0.082 & 0.077 \\
\hline$F(000)$ & 400 & 800 & 400 \\
\hline Crystal size $\left(\mathrm{mm}^{3}\right)$ & $0.200 \times 0.100 \times 0.050$ & $0.080 \times 0.050 \times 0.030$ & $0.050 \times 0.050 \times 0.020$ \\
\hline Theta range for data collection $\left({ }^{\circ}\right)$ & 4.054 to 28.698 & 4.015 to 27.482 & 4.321 to 27.481 \\
\hline \multirow[t]{3}{*}{ Index ranges } & $-7 \leq h \leq 7$ & $-7 \leq h \leq 7$ & $-7 \leq h \leq 7$ \\
\hline & $-10 \leq k \leq 10$ & $-9 \leq k \leq 9$ & $-9 \leq k \leq 9$ \\
\hline & $-27 \leq I \leq 27$ & $-52 \leq I \leq 52$ & $-27 \leq I \leq 27$ \\
\hline
\end{tabular}




\begin{tabular}{|c|c|c|c|}
\hline Reflections collected & 16883 & 23776 & 15435 \\
\hline \multirow[t]{2}{*}{ Independent reflections } & 4849 & 7991 & 8332 \\
\hline & {$[R($ int $)=0.0403]$} & {$[R($ int $)=0.0968]$} & {$[R($ int $)=0.0501]$} \\
\hline \multirow[t]{2}{*}{ Completeness (\%) } & 99.60 & 99.60 & 99.60 \\
\hline & $\left(\right.$ theta $\left.=25.242^{\circ}\right)$ & $\left(\right.$ theta $\left.=25.242^{\circ}\right)$ & $\left(\right.$ theta $\left.=25.242^{\circ}\right)$ \\
\hline \multirow[t]{2}{*}{ Absorption correction } & Semi-empirical & Semi-empirical & Semi-empirical \\
\hline & from equivalents & from equivalents & from equivalents \\
\hline Max. and min. transmission & 1.00000 and 0.95198 & 1.00000 and 0.66352 & 1.00000 and 0.88763 \\
\hline \multirow[t]{2}{*}{ Refinement method } & Full-matrix least-squares & Full-matrix least-squares & Full-matrix least-squares \\
\hline & on $\mathrm{F}^{2}$ & on $\mathrm{F}^{2}$ & on $\mathrm{F}^{2}$ \\
\hline Data / restraints / parameters & 4849 / 132 / 325 & 7991 / 2 / 541 & 8332 / 3 / 541 \\
\hline Goodness-of-fit on $\mathrm{F}^{2}$ & 1.041 & 0.985 & 1.004 \\
\hline \multirow[t]{2}{*}{ Final $R$ indices $[I>2$ sigma $(I)]$} & $\mathrm{R} 1=0.0614$ & $\mathrm{R} 1=0.0678$ & $\mathrm{R} 1=0.0609$ \\
\hline & $w R 2=0.1437$ & $w R 2=0.1212$ & $w R 2=0.1277$ \\
\hline \multirow[t]{2}{*}{$\mathrm{R}$ indices (all data) } & $\mathrm{R} 1=0.1002$ & $\mathrm{R} 1=0.1290$ & $\mathrm{R} 1=0.1131$ \\
\hline & $w R 2=0.1664$ & $w R 2=0.1421$ & $w R 2=0.152$ \\
\hline Largest diff. peak and hole $\left(\mathrm{e} \cdot \AA^{-3}\right)$ & 0.384 and -0.257 & 0.239 and -0.296 & 0.336 and -0.262 \\
\hline
\end{tabular}




\section{Device Fabrication and Evaluation}

The field-effect mobility of terazulene isomers (TAz1, TAz2, TAz3, and TAz4) was measured using top-contact thin-film field-effect transistor (FET) geometry. A heavily doped $n^{+}-\operatorname{Si}(100)$ substrate functioned as the gate electrode. A $300 \mathrm{~nm}$-thick $\mathrm{SiO}_{2}$ dielectric layer with a capacitance of $11.8 \mathrm{nF} \mathrm{cm}{ }^{-2}$ was thermally grown on the gate substrate. Thin films of TAz1, TAz2, TAz3, and TAz4 as the active layer were vacuum-deposited onto octadecyl trichlorosilane (ODTS)-treated $\mathrm{Si} / \mathrm{SiO}_{2}$ substrates at different temperatures $\left(T_{\text {sub }}=\mathrm{RT}, 60,100{ }^{\circ} \mathrm{C}\right)$ at a rate of $0.3 \AA \mathrm{s}^{-1}$ under a pressure of $\sim 1.0 \times 10^{-6} \mathrm{~Pa}$. Gold or aluminum films (40 nm or $80 \mathrm{~nm}$, respectively) were deposited through a shadow mask on top of the organic thin films as drain and source electrodes. For a typical device, the drain-source channel length $(L)$ and width $(W)$ are $50 \mu \mathrm{m}$ and $5.5 \mathrm{~mm}$, respectively. The characteristics of the OFET devices were measured at room temperature under nitrogen with an Agilent Technologies $4155 \mathrm{C}$ semiconductor parameter analyzer operated by the Interactive Characterization Software (ICS), version 3.6.0. Field-effect mobility $\left(\mu_{\mathrm{FET}}\right)$ was calculated from the transfer curves in the saturation regime $\left(V_{\mathrm{D}}=100 \mathrm{~V}\right)$ of the $I_{\mathrm{D}}$ using the following equation:

$I_{\mathrm{D}}=\left(W C_{i} / 2 L\right) \mu_{\mathrm{FET}}\left(V_{\mathrm{G}}-V_{\mathrm{Th}}\right)^{2}$

where $C_{i}$ is the capacitance of the $\mathrm{SiO}_{2}$ insulator and $V_{\mathrm{G}}$ and $V_{\mathrm{Th}}$ are the gate and threshold voltages, respectively.
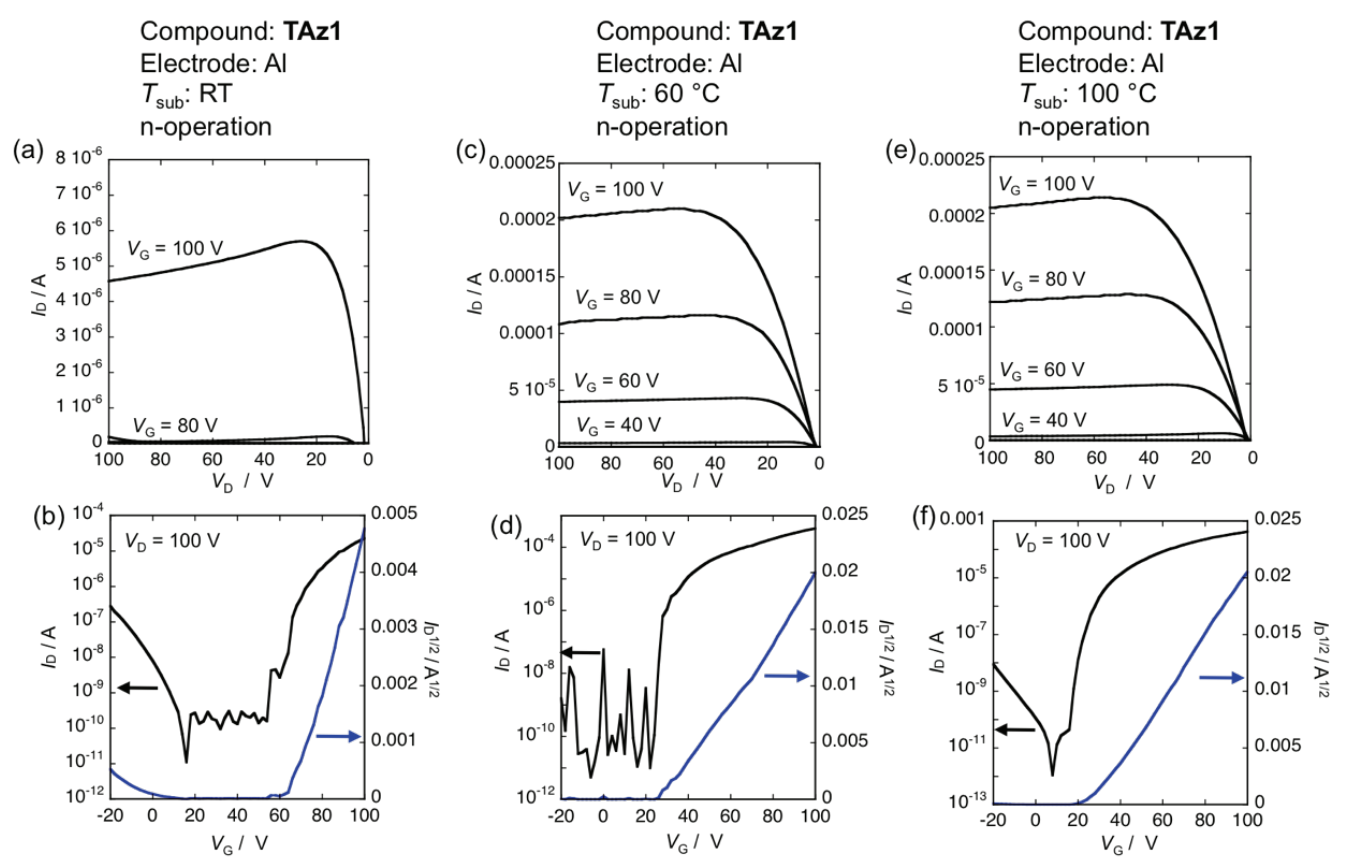

Figure S17. Typical OFET characteristics of top-contact devices (electrode $=\mathrm{Al}$ ) fabricated using TAz1. (a, c, e) Output curves at different gate voltages. (b, d, f) Transfer curves in the saturated region. 

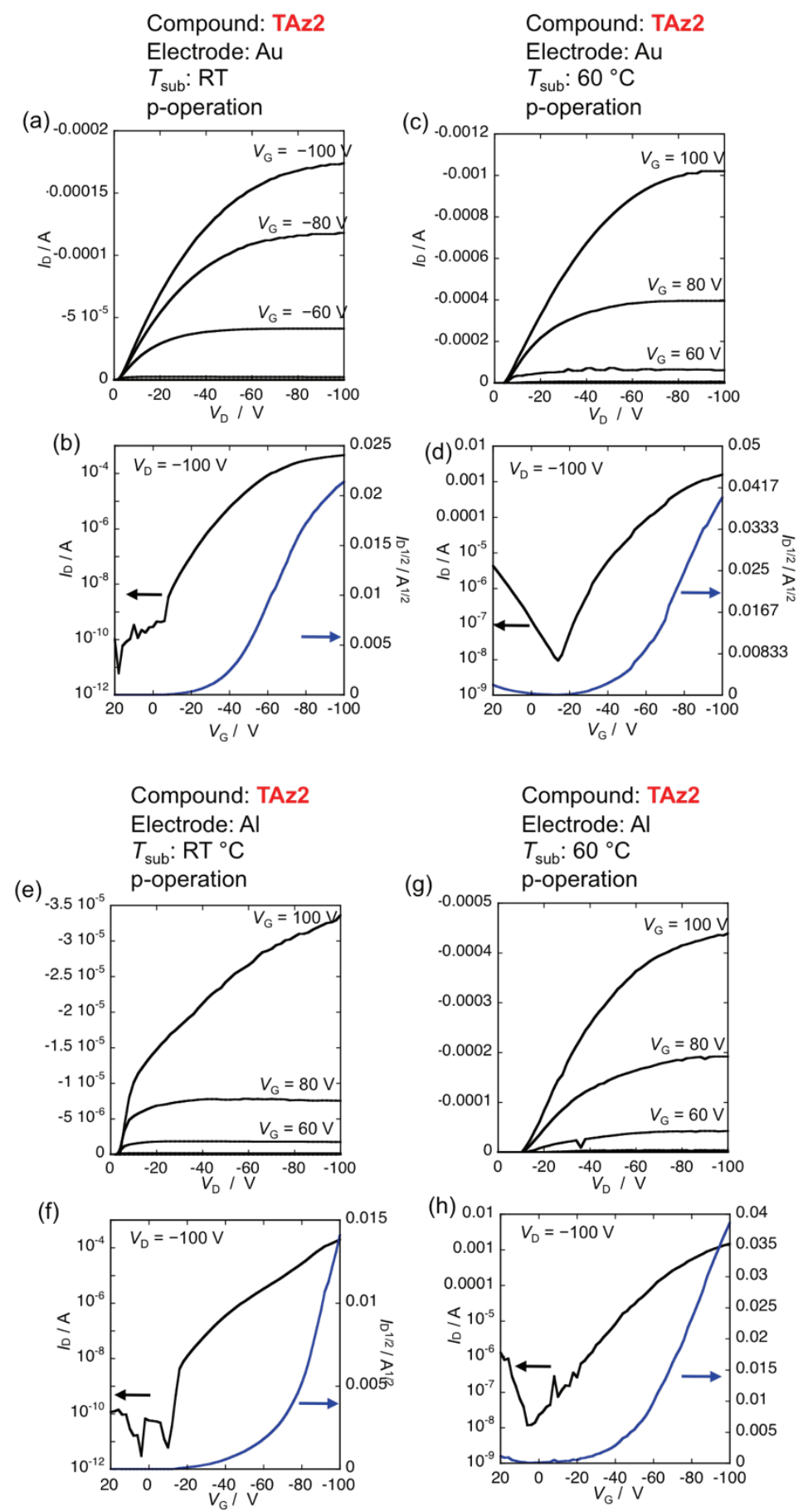

Figure S18. Typical OFET characteristics of top-contact devices (electrode $=\mathrm{Au}$ or $\mathrm{Al}$ ) fabricated using TAz2. (a, c, e, g) Output curves at different gate voltages. (b, d, f, h) Transfer curves in the saturated region. 

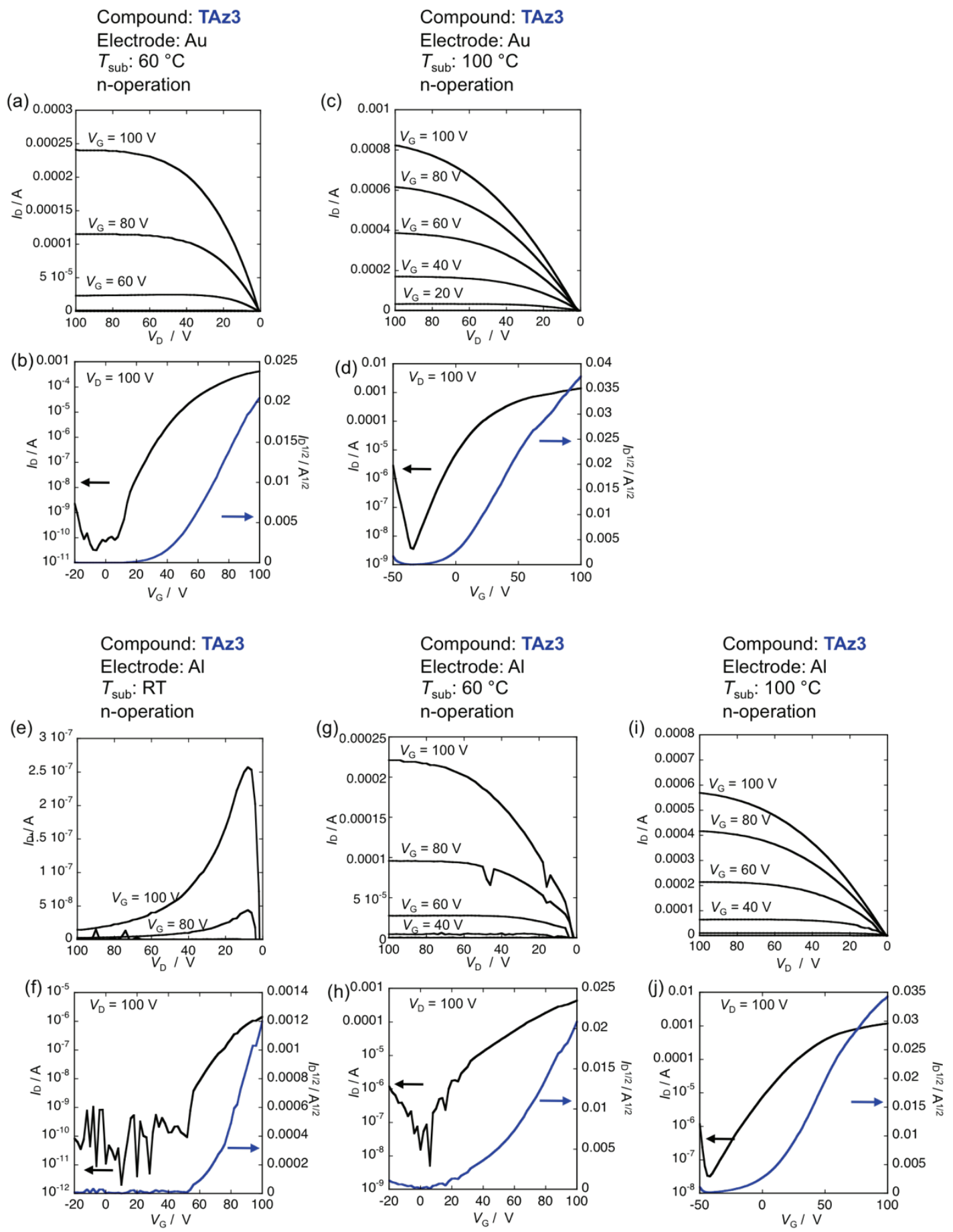

Figure S19. Typical OFET characteristics of top-contact devices (electrode $=\mathrm{Au}$ or $\mathrm{Al}$ ) fabricated using TAz3. (a, c, e, g, i) Output curves at different gate voltages. (b, d, f, h, j) Transfer curves in the saturated region. 

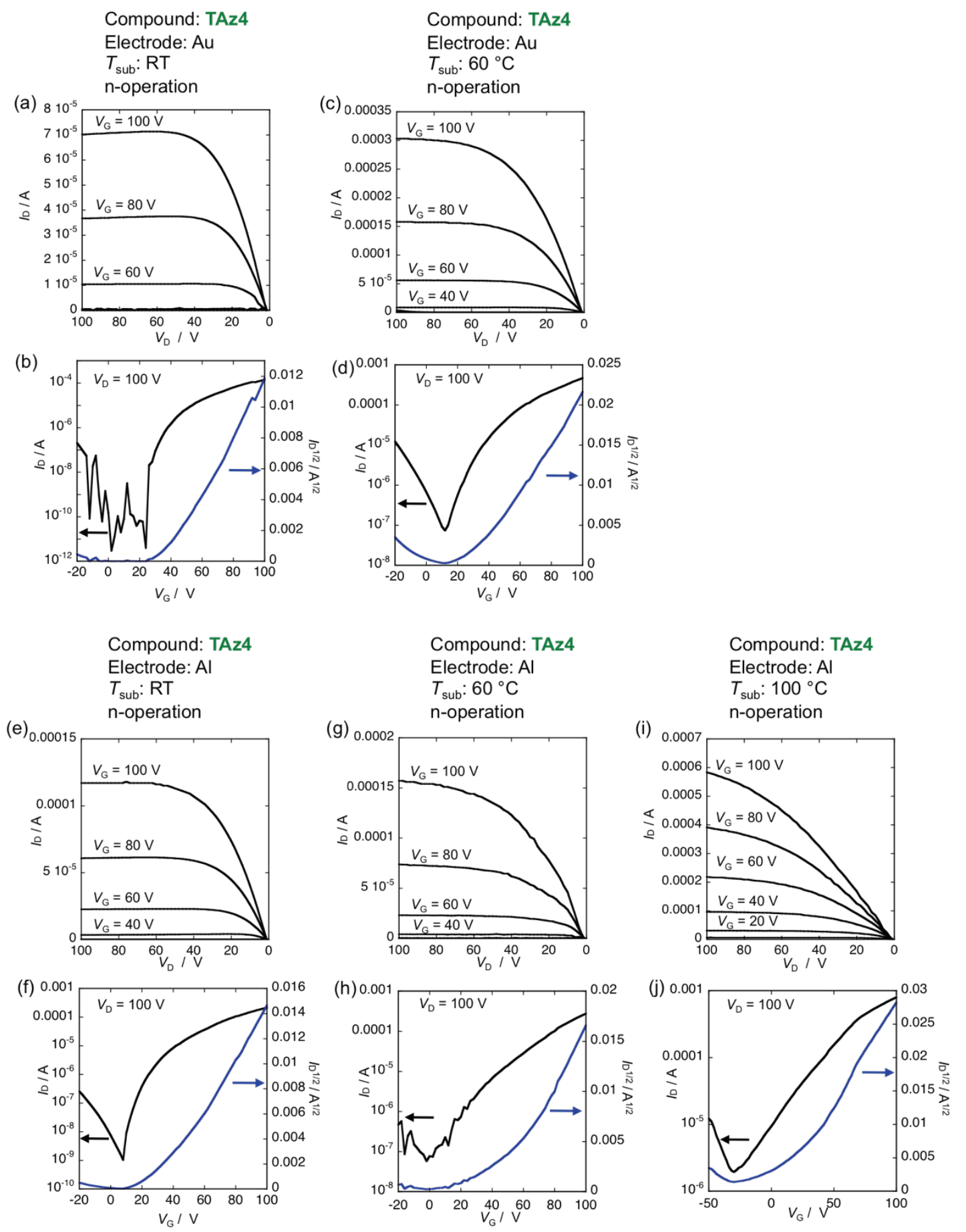

Figure S20. Typical OFET characteristics of top-contact devices (electrode $=\mathrm{Au}$ or $\mathrm{Al}$ ) fabricated using TAz4. (a, c, e, g, i) Output curves at different gate voltages. (b, d, f, h, j) Transfer curves in the saturated region. 


\section{Thin film X-ray diffraction measurement.}

2D-GIXD measurements were performed in a HUBER multiaxis diffractometer installed in beamline BL19B2 at SPring- 8 . The X-ray beam was monochromatized by a double-crystal Si(111) monochromator, and the X-ray energy was $12.40 \mathrm{keV}$ and the $\mathrm{X}$-ray beam size was $50 \mu \mathrm{m}(\mathrm{H}) \times 300$ $\mu \mathrm{m}(\mathrm{W})$ at the sample position. The diffraction from samples was detected by an X-ray photon counting pixel detector (PILATUS $300 \mathrm{~K}$ ). The X-ray beam incidence angle was set to $0.12^{\circ}$, and the camera length (sample-to-detector distance) was about $175 \mathrm{~mm}$. The sample size for the 2D-GIXD measurements was $10 \mathrm{~mm}$ in width, $10 \mathrm{~mm}$ in length and $0.5 \mathrm{~mm}$ in thickness. 2D-GIXD measurements were performed in the air at room temperature. The exposure time was $30 \mathrm{sec}$. Because the exposure time was short, no irradiation damage was detected.
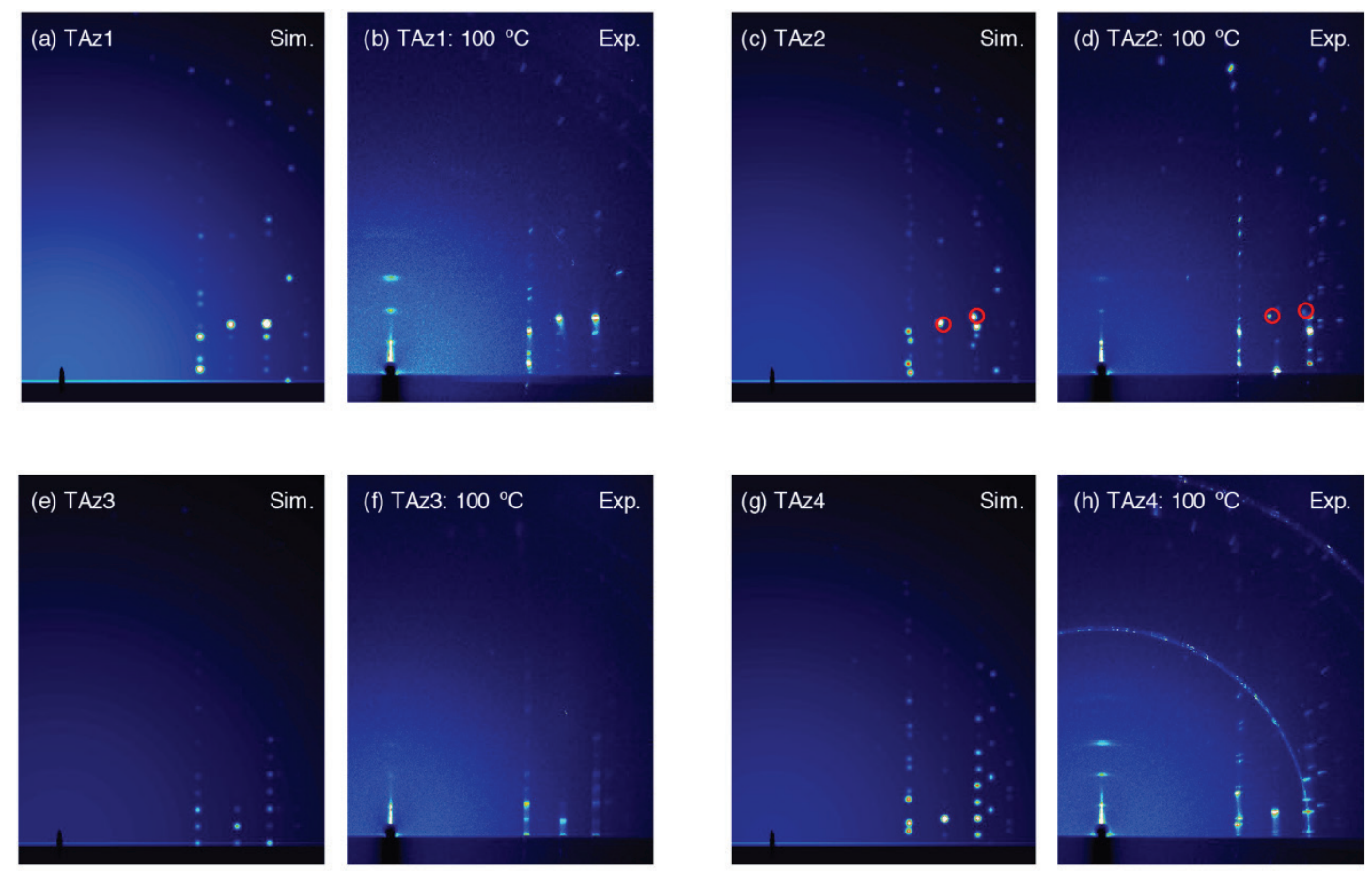

Figure S21. Simulated and experimental 2D-GIXD patterns of TAz1-TAz4 thin films. The simulated patterns were calculated on the basis of the single-crystal data using a homemade software. The experimental data at $T_{\text {sub }}=100{ }^{\circ} \mathrm{C}$ were used. The Miller indices $(h k l)$ illustrated in Figure 6 were assigned on the basis of the single-crystal data. In TAz2, (c) and (d), the red circles were assigned as an original unit cell and the other peaks differed slightly from the single-crystal data. 

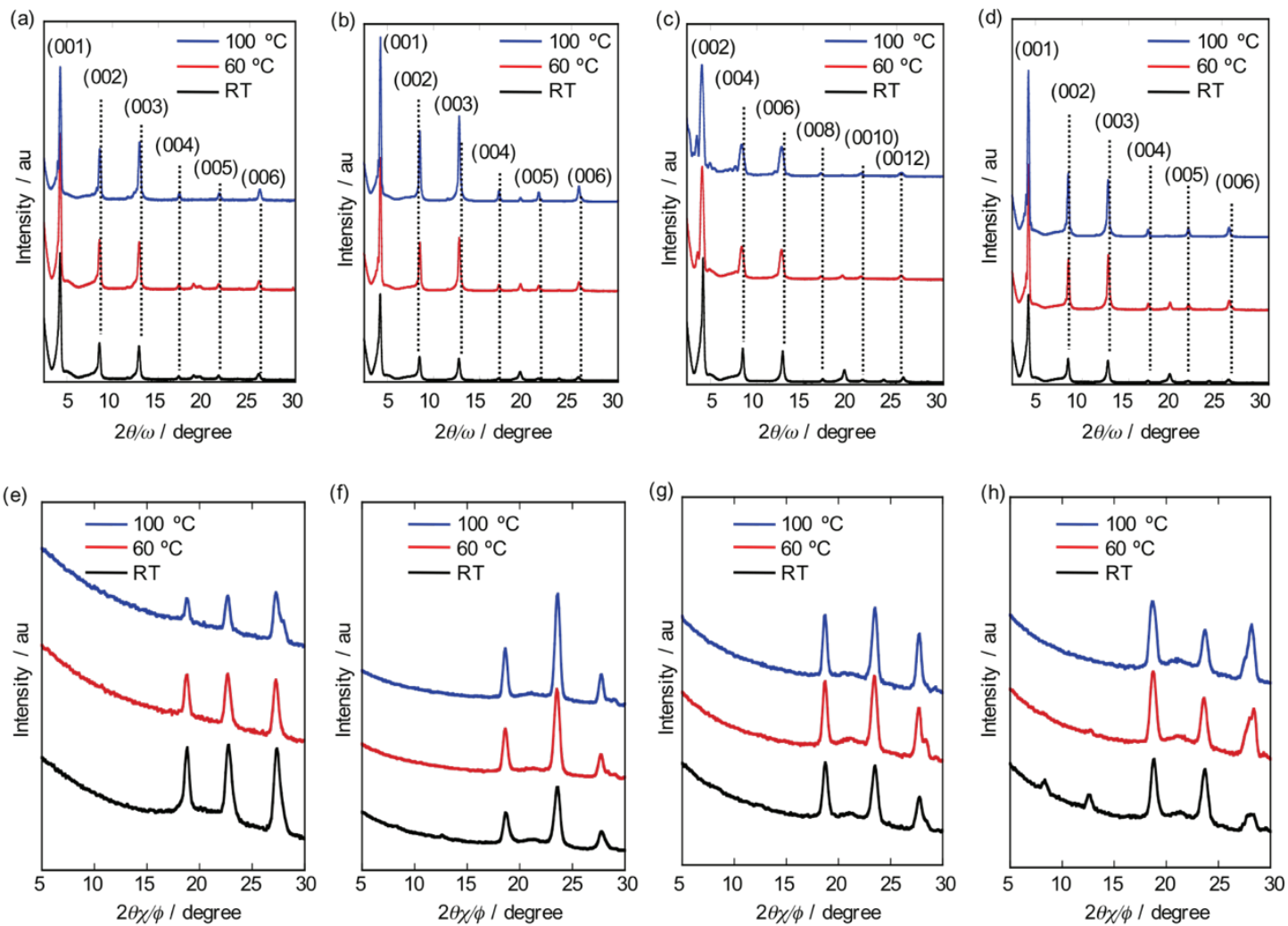

Figure S22. XRD analysis of evaporated thin films of TAz1-TAz4 deposited onto ODTS-treated $\mathrm{Si} / \mathrm{SiO}_{2}$ substrates at different substrate temperatures: Out-of-plane X-ray diffraction patterns of TAz1 (a), ${ }^{1)}$ TAz2 (b), TAz3 (c), and TAz4 (d). In-plane X-ray diffraction patterns of TAz1 (e), TAz2 (f), TAz3 (g), and TAz4 (h). The data for the in-plane measurement of TAz1 were collected with the detector angle fixed at $2 \theta / \omega=7^{\circ}$.

\section{Theoretical Calculations}
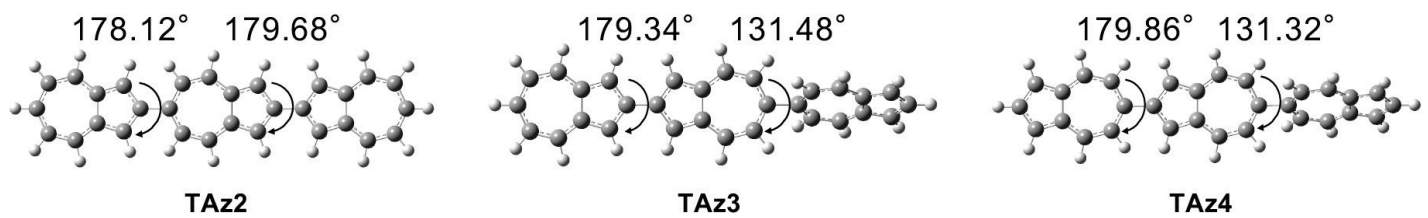

Figure S23. Optimized structures of TAz2-TAz4. All calculations were performed using the Gaussian 09 program. ${ }^{6}$ The geometries were optimized at the B3LYP/6-31G(d) level without any symmetry constraints. The two dihedral angles of azulene planes were fixed during structure optimization at the angles determined from refinement of the crystal structures. 
Table S2. Summary of DFT calculation results for TAz2-4.

\begin{tabular}{cccc}
\hline Compound & TAz2 & TAz3 & TAz4 \\
\hline E(RB3LYP) (a.u.) & -1155.14184164 & -1155.13614719 & -1155.12789750 \\
Imaginary freq & 1 & 0 & 1 \\
Dipole moment (Debye) & 1.8166 & 1.4206 & 1.9017 \\
\hline
\end{tabular}

(a)

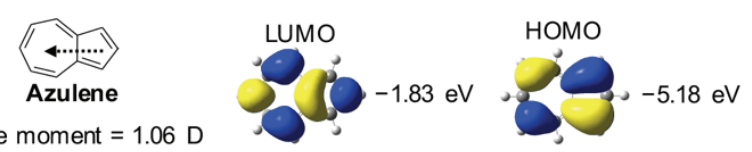

(b)

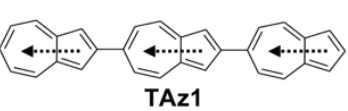

Dipole moment $=5.30 \mathrm{D}$

LUMO+3 - $1.10 \mathrm{eV}$

LUMO+1

$\Delta E=0.89 \mathrm{eV}$

LUMO

HOMO

$\Delta E=0.29 \mathrm{eV}$

HOMO-1 38

$\Delta E=0.22 \mathrm{eV}$

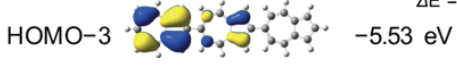

(d)

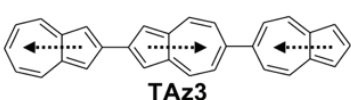

Dipole moment $=1.42 \mathrm{D}$

LUMO+2

LUMO+1

$\Delta E=0.71 \mathrm{eV}$

LUMO

НОМо -

$\Delta \mathrm{E}=0.05 \mathrm{eV}$

HOMO-1

HOMO-2 (c)

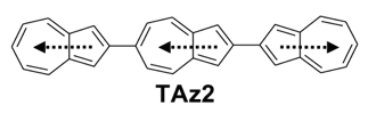

Dipole moment $=1.82 \mathrm{D}$

LUMO+3 forfocio: $-1.09 \mathrm{eV}$

LUMO+1 की

$\Delta \mathrm{C}=0.79 \mathrm{eV}$

LUMO

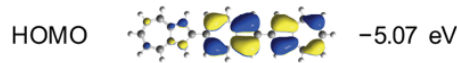

HOMO-2 \%

$\Delta \mathrm{E}=0.16 \mathrm{eV}$

номо-з Сृ:- $\because \because-5.41 \mathrm{eV}$

$\Delta \mathrm{E}=0.18 \mathrm{eV}$

(e)

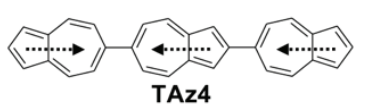

Dipole moment $=1.90 \mathrm{D}$

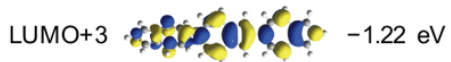
$\Delta \mathrm{E}=0.69 \mathrm{eV}$

LUMO+1 G0:06 $-1.91 \mathrm{eV}$

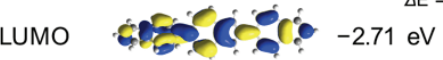
$\Delta \mathrm{E}=0.80 \mathrm{eV}$

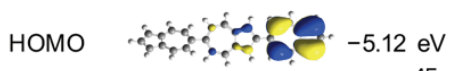

$\Delta E=0.23 \mathrm{eV}$

номо-1 $28 \therefore \therefore \circ-5.35 \mathrm{eV}$

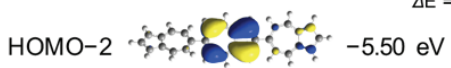

Figure S24. HOMOs and LUMOs of terazulene isomers: these HOMOs and LUMOs are derived from the HOMO and the LUMO of a neat azulene; other HOMOs and LUMOs, such as HOMO-2 of TAz1, which is assigned as HOMO-1 of neat azulene, are not displayed. 


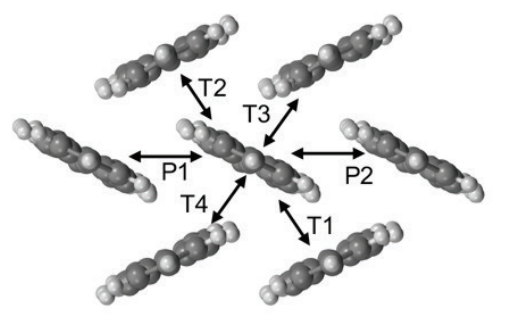

TAz1 and TAz2

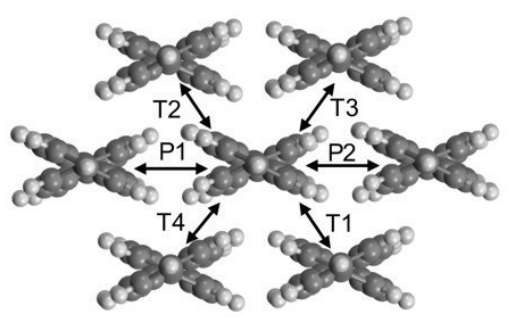

TAz3 and TAz4

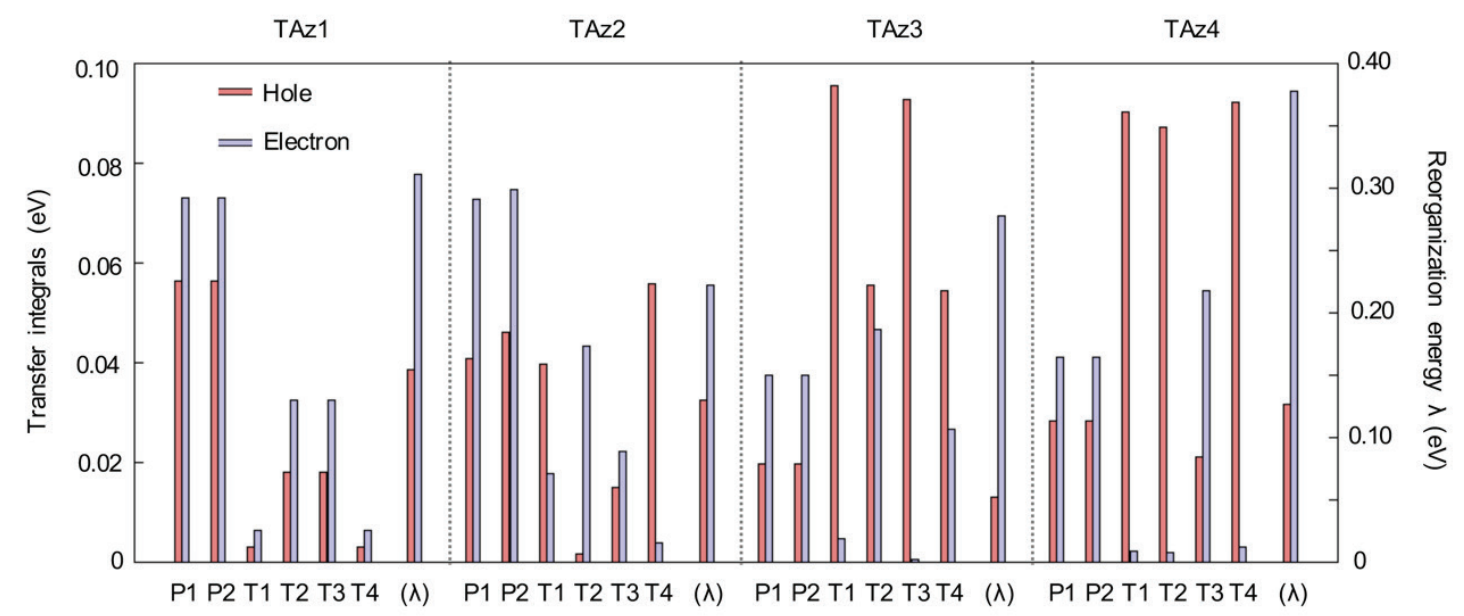

Figure S25. Reorganization energies $(\lambda)$ and transfer integrals in TAz1-TAz4. The reorganization energies were calculated using the Gaussian 09 program. ${ }^{6}$ Transfer integrals were determined from the PW91/TZ2P calculations using the ADF package. ${ }^{7)}$ These transfer integrals are given as absolute values because the electron-transfer rate depends on the square of the transfer integral in Marcus theory. The molecular coordinates determined by X-ray diffraction analysis of single crystals were used without further geometry optimization, where the crystal systems of TAz1 and TAz2 were converted to $P 2_{1}$ and $P 1$, respectively, because of their global disorder structures. 


\section{References}

(1) Yamaguchi, Y.; Ogawa, K.; Nakayama, K.-I.; Ohba, Y.; Katagiri, H. J. Am. Chem. Soc. 2013, 135 (51), 19095-19098.

(2) CrysAlisPro CCD, CrysAlisPro RED and ABSPACK in CrysAlisPro RED. Oxford Diffraction Ltd, Abingdon, England, 2006.

(3) SHELXT: Sheldrick, G. M. Acta Cryst. A 2015, 71, 3-8.

(4) SHELXL2014: Sheldrick, G. M. Acta Cryst. C 2015, 71, 3-8.

(5) (a) Yadokari-XG: Wakita, K. Software for crystal Structure Analyses, 2001. (b) Yadokari-XG 2009: Kabuto, C.; Akine, S.; Nemoto, T.; Kwon, E. J. Cryst. Soc. Jpn. 2009, 51, 218-224.

(6) Gaussian 09, Revision D.01: Frisch, M. J.; Trucks, G. W.; Schlegel, H. B.; Scuseria, G. E.; Robb, M. A.; Cheeseman, J. R.; Scalmani, G.; Barone, V.; Mennucci, B.; Petersson, G. A.; Nakatsuji, H.; Caricato, M.; Li, X.; Hratchian, H. P.; Izmaylov, A. F.; Bloino, J.; Zheng, G.; Sonnenberg, J. L.; Hada, M.; Ehara, M.; Toyota, K.; Fukuda, R.; Hasegawa, J.; Ishida, M.; Nakajima, T.; Honda, Y.; Kitao, O.; Nakai, H.; Vreven, T.; Montgomery, Jr., J. A.; Peralta, J. E.; Ogliaro, F.; Bearpark, M.; Heyd, J. J.; Brothers, E.; Kudin, K. N.; Staroverov, V. N.; Kobayashi, R.; Normand, J.; Raghavachari, K.; Rendell, A.; Burant, J. C.; Iyengar, S. S.; Tomasi, J.; Cossi, M.; Rega, N.; Millam, N. J.; Klene, M.; Knox, J. E.; Cross, J. B.; Bakken, V.; Adamo, C.; Jaramillo, J.; Gomperts, R.; Stratmann, R. E.; Yazyev, O.; Austin, A. J.; Cammi, R.; Pomelli, C.; Ochterski, J. W.; Martin, R. L.; Morokuma, K.; Zakrzewski, V. G.; Voth, G. A.; Salvador, P.; Dannenberg, J. J.; Dapprich, S.; Daniels, A. D.; Farkas, Ö.; Foresman, J. B.; Ortiz, J. V.; Cioslowski, J.; Fox, D. J. Gaussian, Inc., Wallingford CT, 2009.

(7) ADF2016, SCM, Theoretical Chemistry, Vrije Universiteit,. Amsterdam, The Netherlands, http://www.scm.com (accessed Feb 15, 2016). 